\title{
Risk Factors for Newly Diagnosed Hypertensive at Non- Diabetes Participants: A Cohort Study in Central Bogor, Indonesia
}

\author{
Eva Sulistiowati ${ }^{1 *}$, Marice Sihombing ${ }^{1}$ \\ ${ }^{I}$ Center for Research and Development of Resources and Health Services, Jakarta, Indonesia \\ "Corresponding author.Email: dr.eva_s@yahoo.com
}

\begin{abstract}
Hypertension is a major contributor to cardiovascular disease. Hypertension is known as the silent killer disease. The patients do not feel any symptoms or asymptomatic and for a long time, if it is not be cured they will get some complications. The prevalence of hypertension is rising in the world including Indonesia. This aim of the study is to assess the risk factors for newly diagnosed hypertension at non-diabetes respondents in the Cohort Study of Risk Factors for Non-Communicable Diseases in Central Bogor. We conducted a prospective study, the sample was respondents from baseline data Cohort Study 2011-2012 that they were not diagnosed hypertensive with JNC VII criteria, and not diabetes mellitus with ADA criteria (3984 persons), conducted follow-up for 6 years. Data collected by interviews, physical examinations (weight, height, abdominal circumference, blood pressure), and laboratories (fasting plasma glucose and 2 hours after loading $75 \mathrm{~g}$ of glucose, total cholesterol, HDL, LDL, triglycerides). We used multiple logistic regression for analysis and odd ratios with $95 \%$ confidence intervals were calculated to identify risk factors associated with hypertension. The incidence of hypertension increases every year and proportion of cumulative in 6 years was 770 persons (19.32\%), 219 mens (28.4\%) and 551 womens (71.6\%). Hypertensive participants had higer levels for fasting plasma glucose and 2 hours after loading, triglycerides and LDL than normotensive $(\mathrm{p}<0.001)$. Risk factors assosiated with hypertension are age $\geq 45$ years $(\mathrm{OR}=1.31 ; 95 \% \mathrm{CI}=1.114-1.549)$, obesity $(\mathrm{OR}=1.89 ; 95 \% \mathrm{CI}=1.592-2.250)$, diabetes $(\mathrm{OR}=2.31 ; 95 \% \mathrm{CI}=1.674-3.182)$, high $\mathrm{LDL}(\mathrm{OR}=1.59$; 95\% $\mathrm{CI}=1.303-1.947)$, and stress $(\mathrm{OR}=2.5$; 95\% $\mathrm{CI}=1.985-3.166)$ with $\mathrm{p} \leq 0.05$. Age, obesity, diabetes, high LDL and stress are important risk factors associated with hypertension. Most of the risk factors can be modified and require prevention efforts with lifestyle changes.
\end{abstract}

Keywords: hypertension, risk factors, non-diabetes participants, cohort study

\section{INTRODUCTION}

Hypertension or high blood pressure is an abnormal increase in blood pressure, both systolic $(\geq 140 \mathrm{mmHg})$ and diastolic $(\leq 90 \mathrm{mmHg}$ ) [1]. Hypertension is one of the important factors triggering non-communicable diseases (NCD) such as heart disease, stroke, and diabetes [2]. Hypertension is also known as the silent killer disease because the patients do not feel any disturbances or symptoms (asymptomatic) for a long time until the patients having complications that lead to death [2][3].

The prevalence of hypertension continues to increase in many countries including Indonesia. The World Health Organization (WHO) predicts the number of hypertension continues to increase with population growth [4]. Riskesdas 2013 results stated that the prevalence of hypertension at population $\geq 18$ years old in Indonesia according to the measurement results was $25.8 \%$, and the prevalence of hypertension based on the diagnosis of health workers was $9.4 \%$, but those taking hypertension medication only 9.5\%.5 Based on the Riskesdas reports there is a significant difference between blood pressure measurements in the field and those diagnosed with hypertension by health workers. This shows that the prevalence of hypertension in the community is higher. Because hypertension does not have specific symptoms so most people do not know that they have suffered hypertension or they knew hypertension but they do not come to health care providers for adequate treatment [5].

Various factors can cause hypertension. Age and genetics are risk factors that can not be controlled. The results of the previous analysis showed that the risk factors associated with the occurrence of hypertension are high salt consumption, obesity, smoking, lack of activity, stress, and an increase/decrease in blood lipid levels (dyslipidemia). All of these risk factors actually can be controlled with a healthy life style [6].

The aims of the study are to obtain various risk factors for newly diagnosed hypertension at non-diabetes 
was determined with the glucose hexokinase II (GLUH) method, total cholesterol with a standard enzymatic method, LDL and HDL cholesterol was determined by a standard homogeneous method, while for triglyceride measurement the glycerol-3-phosphate oxidase (GPO) method was used. These investigations were performed with the Hitachi model 747 automatic analyzer. The subjects were said to be at risk if they had a total cholesterol concentration of $>200 \mathrm{mg} / \mathrm{dL}$, triglyceride concentration of $>150 \mathrm{mg} / \mathrm{dL}$, LDL cholesterol $>100$ $\mathrm{mg} / \mathrm{dL}$, and HDL cholesterol $<40 \mathrm{mg} / \mathrm{dL}$ for males and $<50 \mathrm{mg} / \mathrm{dL}$ for females. A second blood sample of $1 \mathrm{ml}$ was collected 2 hours post-loading with $75 \mathrm{~g}$ glucose. These blood samples were handled similarly as in the blood glucose determination [8][9].

\section{RESULTS AND DISCUSSION}

\section{Results}

The analysis showed that there were 2496 female respondents who were not hypertensive and non-DM $(62.7 \%)$ and $1488(37.3 \%)$ men. Based on the age group it was found that the age group $<45$ years were 2543 people $(63.9 \%)$ while the age of $\geq 45$ years was 1441 people $(36.1 \%)$. There are about $26.5 \%$ of respondents who experience stress (Table 1).

Table 1. Frequency distribution of respondents who are not hypertensive and non-DM $(\mathrm{N}=3984)$

\begin{tabular}{|c|c|c|}
\hline $\begin{array}{c}\text { Variables } \\
\text { Gender }\end{array}$ & $\begin{array}{c}\text { number of } \\
\text { respondents (n) }\end{array}$ & $\begin{array}{c}\text { percentage } \\
(\%)\end{array}$ \\
men & 1488 & 37,3 \\
women & 2496 & 62,7 \\
Age (y.o) & & \\
$<45$ & 2543 & 63,9 \\
$\geq 45$ & 1441 & 36,1 \\
Obese (BMI $\geq 25)$ & & \\
No & 2607 & 65,4 \\
Yes & 1377 & 34,6 \\
Stress & & \\
No & 2925 & 73,5 \\
Yes & 1056 & 26,5 \\
\hline
\end{tabular}

The number of respondents who have hypertension increases with time (Figure 1). In the first year of observation, it was known that respondents were hypertensive as many as 134 people, then in the second year it increased to 332 people (total from the first and second years). In the 6th year, the total number of respondents who had hypertension was 770 people $(19.32 \%)$. 


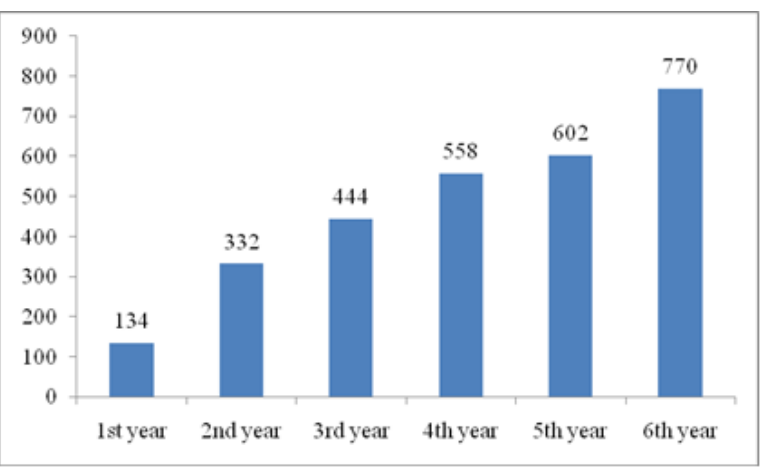

Figure 1. The incidence of hypertension in the 1st until 6th years follow up
Table 2 shows the proportion of hypertension was higher in women $(71.6 \%)$ than in men $(28.4 \%)$. Based on the age group it is known that the age group $\geq 45$ years the proportion is higher (58.8\%) compared to the age <45 years $(41.2 \%)$. In obese participants, the proportion of hypertension was higher $(58.7 \%)$ than those who were not obese. Based on blood tests found that respondents who have high LDL cholesterol levels, the proportion of hypertension is higher $(74.7 \%)$ compared to participants with normal LDL cholesterol (25.3\%).

Table 2. Proportion of hypertension according to respondent characteristics $(n=3984)$

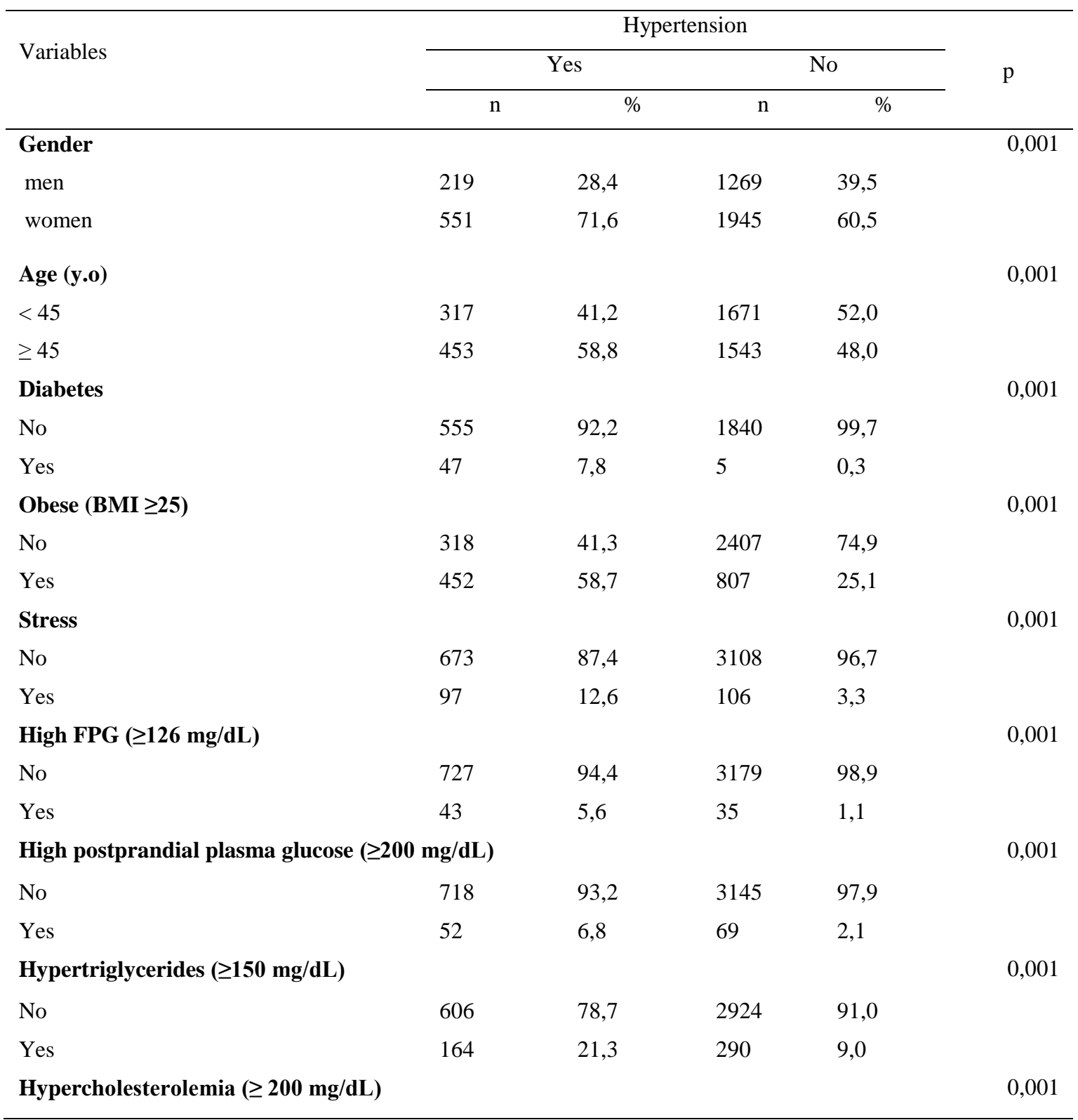




\begin{tabular}{|c|c|c|c|c|c|}
\hline \multirow{2}{*}{$\begin{array}{l}\text { No } \\
\text { Non-1n }\end{array}$} & \multicolumn{4}{|c|}{ Hypertension } & \multirow{2}{*}{$\mathrm{p}$} \\
\hline & 452 & 58,7 & 2374 & 73,9 & \\
\hline Yes & 318 & 41,3 & 840 & 26,1 & \\
\hline Low cholesterol HDL & & & & & 0,001 \\
\hline No & 503 & 65,3 & 2545 & 79,2 & \\
\hline Yes & 267 & 34,7 & 669 & 20,8 & \\
\hline High cholesterol LDL & & & & & 0,001 \\
\hline No & 195 & 25,3 & 1745 & 54,3 & \\
\hline Yes & 575 & 74,7 & 1469 & 45,7 & \\
\hline
\end{tabular}

Table 3 shows the average fasting blood sugar levels in respondents who were hypertensive higher $(98.0 \pm 24.3$ $\mathrm{mg} / \mathrm{dL}$ ) compared to those without hypertension (89.8 \pm $16.8 \mathrm{mg} / \mathrm{dL}$ ) with $\mathrm{p}=0.001$. The same thing was also shown blood sugar levels 2 hours after loading, triglyceride, and LDL levels were significantly different between respondents who had hypertension and those who did not $(\mathrm{p}=0.001)$.

Table 3. The average of blood sugar and lipid levels in respondents

\begin{tabular}{|c|c|c|c|}
\hline \multirow{3}{*}{ Variables } & \multicolumn{2}{|c|}{ Hypertension } & \multirow{3}{*}{$\mathrm{p}$} \\
\hline & Yes & No & \\
\hline & Mean \pm SD & Mean \pm SD & \\
\hline$\overline{\mathrm{FPG}}$ & $98,0 \pm 24,3$ & $89,8 \pm 16,8$ & 0,001 \\
\hline $\begin{array}{ll}\text { PP } & \text { plasma } \\
\text { glucose } & \end{array}$ & $139,9 \pm 52,7$ & $122,4 \pm 36,2$ & 0,001 \\
\hline Cholesterol & $198,3 \pm 34,3$ & $195,9 \pm 35,9$ & 0,128 \\
\hline Triglycerides & $125,0 \pm 79,1$ & $105,8 \pm 61,7$ & 0,001 \\
\hline HDL : - man & $43,9 \pm 9,3$ & $45,8 \pm 10,2$ & 0,021 \\
\hline - women & $53,6 \pm 11,2$ & $54,2 \pm 10,5$ & 0,288 \\
\hline LDL & $127,1 \pm 31,7$ & $121,9 \pm 29,8$ & 0,001 \\
\hline
\end{tabular}

Table 4. Multivariate analysis of factors affecting hypertension

\begin{tabular}{lcc}
\hline \multicolumn{1}{c}{ Variables } & OR $_{\text {adjusted }}$ & 95\% CI \\
\hline Age (y.o) & & \\
$\quad<45$ & 1 & \\
$\quad \geq 45$ & 1,31 & $1,114-1,549$ \\
Obese (BMI $\geq 25)$ & & \\
$\quad$ No & 1 & $1,592-2,250$ \\
$\quad$ Yes & 1,89 & \\
DM & & \\
$\quad$ No & 1 & $1,674-3,182$ \\
$\quad$ Yes & 2,31 & \\
High Cholesterol & & \\
LDL & & \\
\hline
\end{tabular}

\begin{tabular}{ccc}
\hline Variables & OR $_{\text {adjusted }}$ & $\mathbf{9 5 \%}$ CI \\
\hline No & 1 & \\
Yes & 1,59 & $1,303-1,947$ \\
Stress & & \\
No & 1 & \\
Yes & 2,5 & $1,985-3,166$ \\
\hline
\end{tabular}

The results of multivariate analysis showed that the risk factors for respondents newly diagnosed hypertension were age, obesity, DM, high LDL, stress. The age group $\geq$ 45 years has a 1.3 times risk of experiencing hypertension compared to the age group $\leq 45$ years. Respondents with $\mathrm{BMI} \geq 25$ had a risk of 1.89 times, DM had a risk of 2.31 times, high LDL cholesterol had a risk of 1.59 times and stress had a risk of 2.5 times compared with respondents who were not hypertensive (Table 4).

\section{Discussion}

Hypertension is one of the world's public health problems that needs serious treatment. Uncontrolled hypertension has a close relationship with other non-communicable diseases (NCD) such as coronary heart disease, stroke, type 2 diabetes, and cronic kidney disease [10]. One of risk factors for hypertension that cannot be changed is age. The analysis shows that the incidence of hypertension in non-DM respondents increased with increasing observation time, and with increasing age. The age group $\geq 45$ years have a greater risk of developing hypertension than <45 years. Shikha Singh's research conducted in urban India, and FuJun Wang in China also showed the similar results. In urban areas of India, hypertension that occurs in the age group 25-34, 35-44, 45-54, and 55-64 years respectively $12.9 \%, 24.1 \%, 34.7 \%$, and $32,2 \%$ [11]. In China hypertension occurs in the age group of 20-44 years by $13.0 \%$, ages $45-65$ years $(36.7 \%)$, and $56.4 \%$ of age $\geq 65$ years. ${ }^{12}$ This is due to increasing age, elasticity of the aortic artery wall and arteries will decrease [12]. 
Meanwhile, other risk factors for hypertension are obesity, high cholesterol and blood sugar levels, and stress. NonDM respondents with hypertension had an average body weight, fasting blood sugar level and 2 hours after loading, cholesterol total, LDL cholesterol, triglycerides which were higher and HDL was lower compared to normotensive. This is reinforced by several research results such as the National Non-Communicable Diseases Risk Factor Survey in Uganda which showed that the prevalence of hypertension was higher in respondents with BMI 25-29.9 $\mathrm{kg} / \mathrm{m} 2$ (obese) compared to non-obese (36.3\% vs $24.5 \%$ ) [13]. Rishikesh's study in India on 70 people with hypertension compared with 50 normotensive people as controls showed that fasting blood sugar levels of hypertensive patients were significantly higher than normotensive ones $(98.57 \pm 14.23$ compared to $82.98 \pm$ $9.16 \mathrm{mg} / \mathrm{dL}$ ) [14]. Other studies have also shown that glucose and LDL levels in adolescents with hypertension are higher and HDL is lower than those without hypertension with or without a family history of hypertension [15].

This result was also strengthened from further analysis of the Riskesdas 2013 by Sihombing which showed that the risk of hypertension in DM respondents increased in the age group $\geq 45$ years by 2.63 times, mental emotional disorders 2.19 times, central obesity 1.75 times, total cholesterol 1.68 times, general obesity 1.57 times, not working 1.39 times, low education 1.30 times with $\mathrm{p}<0.05$ [16]. In addition, analysis of previous cohort studies of risk factors NCD data conducted by Sirait and Riyadina showed that incidents hypertension that appeared in one year period (2012) from Kebon Kalapa respondents was $16.8 \%$, while risk factors related to the incidence of hypertension included age, education (low and medium), nutritional status (overweight and obese) and stress [17]. Several other studies also report an association between plasma lipids and hypertension. Blood lipid levels in patients with hypertension are usually higher compared to individuals with normotensive. In hypertensive patients, there was an increase in total cholesterol, LDL cholesterol, and triglyceride levels compared to patients without hypertension ( $\mathrm{p}<0.0005)$, and also found a decrease in HDL cholesterol levels ( $\mathrm{p}<0,0005)$. Low HDL cholesterol is a risk factor for heart disease [18]. Rahmad Feryadi's cross-sectional study of 160 respondents showed that total cholesterol was 2.4 times at risk and triglycerides had a risk of 2.49 times for moderate hypertension and HDL cholesterol and LDL cholesterol did not affect the incidence of hypertension. ( $p>0.05$ ) of the Minangkabau ethnic in Padang [10].

Vanissa's cross sectional study of 117 people in renal and hypertensive polyclinic patients Cipto Mangunkusumo hospital also showed an increase in LDL in uncontrolled hypertension patients $43.8 \%$ and controlled hypertension $20.3 \%$ with $\mathrm{p}<0.006 .{ }^{19}$ Eiji Oda's study of 2,449 men and 1,448 women in Japan with a mean age of $51.5 \pm 9.8$ years (April 2008-March 2009) showed that pearson correlation LDL and systolic blood pressure $=0.194(\mathrm{p}<00001)$; LDL and systolic blood pressure $=0.190$ (p <0001)[20]. Meanwhile, the Riyadina study also showed that triglyceride levels in the blood were significantly associated with uncontrolled hypertension $(\mathrm{p}=0.007)$ in postmenopausal women [21].

The above results show that obesity, diabetes, high LDL levels and stress can actually be avoided because it is a risk factor that can be controlled. Obesity causes increased tubular resorption, an imbalance in natriuresis pressure and causes volume expansion through activation of SNS and RAS so that blood pressure rises [12]. In addition, increases in total cholesterol, LDL cholesterol, triglycerides and decreases in HDL cholesterol levels also play an important role for atherosclerosis [10]. Atherosclerosis will result in thickened artery walls and decreased arterial elasticity. Atherosclerosis can occur in arteries in the brain, heart, kidneys, and other vital organs, and needs to be aware because if it occurs in an artery that supplies blood to the brain it can cause a stroke [22].

Controlling weight gain and maintaining a healthy diet in order to maintain normal glucose and fat levels are key in controlling hypertension. No less important, stress factors must also be controlled. Stress will affect the sympathetic nervous system, releasing catecolamine resulting in an increase in heart rate, increased cardiac output, and blood pressure. Repeated sympathetic nerve activation events will cause circulation failure to return to resting levels followed by stressful events causing hypertension. Questions Several studies have shown that stress can occur in individuals who experience work pressure, household problems, poverty. The Coronary Artery Risk Development in Young Adult (CARDIA) study showed hypertension in 3200 people who experienced pressure at work in the 8 years of follow-up [23]. A systematic review by Gasperin on 6 articles showed that individuals who had a stronger response to the incident stress was $21 \%$ more likely to experience an increase in blood pressure when compared with respondents whose responses were less strong (OR: 1.21; 95\% CI: 1.14-1.28; p <0.001) [24].

Seeing the close relationship of hypertension with cardiovascular disease which is the most common cause of death and thre the risk factors that can be controlled as mentioned above, lifestyle changes are necessary as we age. The implementation of the Healthy Living Community Movement (Germas) includes physical activity, fruit and vegetable consumption, regular health checks that need to be disseminated to all groups. Behavior "CERDIK" must also be applied Cek kondisi kesehatan secara berkala (check our health condition regularly), Enyahkan asap rokok (remove of cigarette smoke), Rajin aktivitas fisik (diligent physical activity), Diet sehat dengan kalori seimbang (healthy diet with balanced calories), Istirahat cukup (adequate rest) dan Kendalikan stres (control stress). Early detection of hypertension can be done by intensifying Posbindu so that greater community can be coverage. In addition, the Healthy Indonesia Program with the Family Approach (PIS-PK), where the puskesmas staff go directly to the houses, bringing family access closer to health facilities can also be used for early detection of hypertension and netted hypertension sufferers who undergo irregular treatment. 
[5] Badan Penelitian dan Pengembangan Kesehatan. Laporan Hasil Riset Kesehatan Dasar (Riskesdas) Indonesia tahun 2013. Jakarta: Badan Penelitian dan Pengembangan Kesehatan Kementerian Kesehatan Republik Indonesia;2014.

[6] Kumar NL, Deepthi J, Rao YN, and Deedi MK. Study of lipid profile, serum magnesium and blood glucose in hypertension. Biology and Medicine. 2010; 2(1): 6-16.

[7] Badan Penelitian dan Pengembangan Kesehatan. Pedoman Pengukuran Studi Kohor Faktor Risiko PTM 2018. Jakarta: Kementerian Kesehatan Republik Indonesia. 2012.

\section{Study of Risk Factors NCD.} all parties who helped further data analysis of Cohort

\section{REFERENCES}

[1] National Heart, Lung, and Blood Institute, National Institute of Health, US. 2004. The seventh report of the Joint Committee on prevention, detection, evaluation, and treatment of high blood pressure. NIH Publication No. 045230, August 2004. (cited 2018 August 2). Available from:http://www.nhlbi.nih.gov/guidelines/hypertension/jnc 7full.pdf.

[2] Hipertensi. The silent killer. Diunduh dari: http://www.pusdatin.kemkes.go.id. Tanggal 29-11-2016.

[3] Hartono B. HIPERTENSI: THE SILENT KILLER. Diunduh dari:

http://www.inash.or.iduploadnews_pdfnews_DR._Drs._Ba mbang_Hartono,_SE26.pdf Tanggal 07-03-2018.

[4] WHO. A global brief on hypertension. Silent killer, global public health crisis. 2013. Diunduh dari: http://ishworld.com/downloads/pdf/global_brief hypertension.pdf. Tanggal 09-03-2018.

[13] Comparative Study. Health and PopulatonPerspectves And Issues. 2014. 37 (1\& 2), 40-49.

[14] Gawatudde D. et al. The Epidemiology of Hypertension in Uganda: Findings from the National NonCommunicable Diseases Risk Factor Survey. PLoS ONE 10(9): e0138991. doi:10.1371/journal.pone.0138991

[15] Pooja, Yashoda Mittal. Fasting Blood Glucose Level in Patients Suffering From Hypertension. Asian Journal of Biomedical and Pharmaceutical Sciences (04). 2014. p 1922.

[16] Villela Baroncini, Castro Sylvestre, Varotto Baroncini,Luz Girol, Précoma, Pecoits Filho. Hypertensive Adolescents: Correlation with Body Mass Index and Lipid and Glucose Profiles. International Journal of Cardiovascular Sciences. 2017. p:401-407.
[8] PERKENI. Konsensus Pengelolaan danPencegahan $\begin{array}{lrcrr}\text { Diabetes } & \text { Melitus } & \text { Tipe } & 2 & \text { di } \\ \text { Indonesia } & 2015 . & \text { Diakses } & \text { dari: }\end{array}$ http://pbperkeni.or.id/doc/konsensus.pdf. tanggal 15 Agustus 2016.

[9] Sulistiowati E, Sihombing M. Perkembangan Diabetes Melitus Tipe 2 dari Prediabetes di Bogor, Jawa Barat. Jurnal Penelitian dan Pengembangan Pelayanan Kesehatan. 2018; 2(1):59-69.

[10] Feryadi R, Sulastri D, dan Kadri H. Hubungan kadar profil lipid dengan kejadian hipertensi pada masyarakat etnik Minangkabau di Kota Padang tahun 2012. Jurnal Kesehatan Andalas. 2014;3(2):206-2011.

[11] Shikha Singh,1 Ravi Shankar,1 and Gyan Prakash Singh. Prevalence and Associated Risk Factors of Hypertension: A Cross-Sectional Study in Urban Varanasi. International Journal of Hypertension. 2017. p 1-10.

[12] Fujun Wang, Tiwari, Hao Wang. Risk Factors for Hypertension in India and China: A [17] Sihombing M. Faktor yang berhubungan dengan hipertensi pada responden diabetes melitus di Indonesia (Data Riskesdas 2013). Buletin Penelitian Kesehatan, Vol. 45, No. 1, Maret 2017: $53-64$.

[18] Sirait AM, Riyadina W. Insiden hipertensi pada Kohor prospektif di Kelurahan Kebon Kalapa Bogor. Buletin Penelitian Sistem Kesehatan. 2013; 16(1): 99-107.

[19] Shu-Zhong Jiang, Wen Lu, Xue-Feng Zong, HongYun Ruan, Yi Liu. Obesity and Hypertension (Review). Experimental and Therapeutic Medicine . 2016.12: 23952399.

[20] Vanissa N, Nugroho P. Hubungan Kadar LowDensity Lipid (LDL) dengan kendali Tekanan Darah pada pasien poliklinik ginjal dan hipertensi IPD di RSCM. FKUI, 20138/25 
[24] Tanya M. Chronic Psychosocial Stress and Hypertension. Curr Hypertens Rep. 2010; 12(1): 10-16.

[25] Gasperin D, Gopalakrishnan Netuvel, Juvenal Soares Dias-da-Costa, Marcos Pascoal. Effect of psychological stress on blood pressure increase: a meta-analysis of cohort studies. Cad. Saúde Pública, Rio de Janeiro. 2009.25(4):715-726.

[23] Lumongga Fitriana. Atherosclerosis. Departemen Patologi Anatomi, Fakultas Kedokteran Universitas Sumatera Utara, Medan. 2007. 